\title{
Success factors for data-driven service delivery networks
}

\author{
Minna Pikkarainen \\ minna.pikkarainen@oulu.fi| University of Oulu, Oulu Business School; Martti Ahtisaari Institute; \\ Medical Imaging Physics and Technologies, P.O. Box 4600, 90014 University of Oulu, Finland \& VTT, \\ Technical research Centre of Finland, Kaitoväylä 1, 90570, Oulu, Finland \\ Tero Huhtala \\ tero.huhtala@oulu.fi| University of Oulu, Oulu Business School, P.O. Box 4600, 90014 University of \\ Oulu, Finland \\ Laura Kemppainen \\ laura.kemppainen@oulu.fi|University of Oulu, Oulu Business School, P.O. Box 4600, 90014 University \\ of Oulu, Finland \\ Juha Häikiö \\ juha.haikio@vtt.fi|VTT, Technical research Centre of Finland, Kaitoväylä 1, 90570, Oulu, Finland
}

\begin{abstract}
Data is becoming a more and more important resource for future innovations. Companies are currently considering how to leverage personal data in preventive healthcare and in other sectors. However, there are many challenges hindering the development of data-driven businesses in extant business networks. The purpose of this paper is to explore the success factors of data-driven service delivery networks in the context of preventive healthcare. The results are examples of the benefits and challenges of data availability and usage, based on a qualitative case study, in which a network of actors is integrating resources to solve the needs of their end customers. The results underline the success factors for service delivery networks, creating a baseline for human-centric, personalized and preventive healthcare solutions. The study enriches the theoretical perspective of data, services and service delivery networks by continuing discussion on how big data resources become cooperative assets not only in a firm but also on the network level. This study has multiple implications for practitioners trying to navigate the turbulent waters of the changing business environment and evolving service delivery network of preventive healthcare. Especially small and medium size of firms could use the identified success factors when planning new data-driven services in their networks. Our analysis brings new perspective between a firm and the actors in its network, particularly in the preventive healthcare sector wherein data needs to be shared between actors via consent of the individuals.
\end{abstract}

Keywords. Success factors; Service delivery network; Healthcare; Human-centric, Data-driven.

Cite paper as: Pikkarainen, M., Huhtala, T., Kemppainen, L., Häikiö, J., (2019). Success factors for data-driven service delivery networks, Journal of Innovation Management, www.open-jim.org, 7(4), 14-46. 


\section{Introduction}

The world is increasingly data-infused and the context in which services are delivered is irrevocably changed by advances in technology. Perhaps the most consequential phenomenon regarding technological innovations' impact on business is the ever-growing volume and velocity of data. It is astounding and deeply disturbing to think that most of the data that exists today have been generated only during the last few years (Grierson, et al., 2015). The use of data is becoming a necessity for organizations that wish to remain competitive. In some cases, data-driven businesses can have 5-6 per cent higher output and productivity than similar organizations that are not using data-driven processes (McAfee, et al., 2012). Marketers are recording a wide range of data, for example what people buy and how often, where they go for vacation, and how often they watch movies. The amount of data that a single person accrues over the years is astounding, for better or for worse. The possibilities that the data entails are huge. Especially the healthcare industry can benefit from the use of wide-ranging personal data (Hood \& Flores, 2012; Ratia, et al., 2018; Beirão, et al., 2017). Holistic utilization of personal data can enable preventive actions and lifestyle changes that could radically decrease the future amount of chronic diseases. For example, studies have found that there is a possibility to lower the risks of Alzheimer's disease and cardiovascular risks, and increase the psychological well-being of people (Ryff, et al., 2004). Therefore, preventive healthcare solutions provide a way to improve health as an outcome. At the same time this is a huge business opportunity for many companies. However, access to all that data requires extensive collaboration at a level of several actors (Huhtala, 2018).

A widely used and accepted term to describe an adaptive collection of collaborating actors is the service ecosystem, which draws heavily from the service-dominant logic (Vargo \& Lusch, 2008). Vargo and Lusch (2016) define a service ecosystem as a complex system of actors that are interconnected by shared institutional arrangements and mutual value creation targets. Servicedominant (S-D) logic describes service as an action of doing something for another party (Vargo \& Akaka, 2009), which works as the fundamental component or basis for economic exchange (Vargo \& Lusch, 2004). The organizations in the ecosystems are contributors that intend to help customers (i.e. an actor that purchases solutions (Sawhney, 2006) to achieve a goal, resolve a problem or satisfy a demand (Bettencourt, et al., 2014). Service ecosystems in S-D logic focus on innovation and the role of institutions - rules, norms, values and beliefs - and institutional arrangements that provide the rules of the game (Koskela-Huotari, et al., 2016). The service ecosystem view concentrates on "the use of resources" and "the integration of skills to develop new knowledge to apply resources in a more effective, efficient, and sustainable manner" (Akaka, et al., 2013). The resource integration process between the actors of the service ecosystem is called co-creation, which emphasizes resource integration, practices and the linking of actors within an ecosystem. These practices can help gain access to resources, manage resource deficiencies and improve the density of resources with the ultimate goal of refining the resources into valuable benefits for the actors, leading to a healthier ecosystem (Frow, et al., 2016).

In S-D logic, value is always customer-centric, and the ecosystem actors create value propositions and do not automatically create value for the customers. Following this background, service ecosystems can be defined as systems that include resource-integrating actors that are working towards value creation through service exchange (Vargo \& Akaka, 2012; Vargo \& Lusch, 2016). 
According to Vargo and Lusch $(2015 ; 2017)$ the conceptual exploration of service ecosystems has just started. Cavities in knowledge still exist, for instance, in regards to what are the uncertainties and opportunities for service ecosystem players when they collaborate to co-create customer value (Vargo \& Lusch, 2015). Additionally, it is important to understand how the service ecosystems evolve (Vargo \& Lusch, 2017). Moreover, it is unclear what the underlying risks and success factors are that relate to resource generation in evolving data-driven ecosystems or networks specifically.

The various uses of data in all sectors of business is an exciting but also an intimidating development. Typically, data is generated by individuals. This means that the individuals' actions have a direct impact on the value creating actions in data-driven service ecosystems. When individuals are continuously participating in the value co-creation process, the interaction between the actors actually generates increased amounts of data to be used by the ecosystems (Xie, et al., 2016). The data sharing between the actors within an ecosystem could bring new opportunities and ways to differentiate the solution to be something that individuals really want and need (Wang, 2012). Although there are many studies that have examined the role of digital platforms in value co-creation (Ceccagnoli, et al., 2012) few, if any, academic studies have explored what factors actually hinder or enable the ongoing change in service ecosystems in the context of the preventive healthcare sector. Service ecosystems describe the interconnectedness of organizations in a systemic perspective. While organizations can be part of a larger service ecosystem that provides them necessary resources, smaller networked entities can be identified within. A more specific concept is needed to explore and describe a network of actors who strive to offer services to end-customers in a holistic sense in a specific domain. The service delivery network (SDN) is a group of organizations that provides a connected service experience to the customer. A service provider may act as a primary organizer directing the service delivery, or have a complementary role in the provision of service. The service itself includes multiple service providers that form a network around the customer. (Tax, et al., 2013).

MyData, a human-centred approach for personal data management, has emerged in Europe to combine this increasing need of companies to work in business ecosystems and access data while simultaneously fulfilling digital human rights. The core idea in the MyData approach is to put individuals (customers) at the centre of value co-creation, letting them decide if their personal data is shared for their, and others', benefit (MyData Alliance, 2017). Although the risks of mishandling the data emerge with its use, it is also a risk for companies not to participate in data-driven ecosystems. Some of the challenges of data-driven business exchange mentioned in the literature are fourfold: i) how to extract data, ii) how to refine data iii) how to ensure data is utilized most effectively (Brownlow, et al., 2015) and iv) how to share the data while fulfilling all the rules and regulations related to data protection at the same time (Graeff \& Harmon, 2002). The data mishandling concern is especially valid in healthcare, in which people are even more concerned about their data usage than in other sectors of the economy. Even though the increasing amount of data is recognized as a new form of capital in the digital era, little research has been done on how the increased amount of data can be capitalized into a valuable asset (Xie, et al., 2016).

The aim of this paper is to understand what the factors affecting to the success and failure of data-driven service delivery networks are in the context of preventive healthcare. To meet this 
aim, we formulated two research questions: 1) How does data, as a resource, affect actions in data-driven service delivery networks? and 2) What are the main challenges to overcome in data-driven service delivery networks?

The work has been conducted as a case study. Because of the systemic nature and interconnectedness of ecosystems and innovation activities, it is necessary to explore "the structure of the ecosystem and its actors and their interrelationships in a particular ecosystem" (Kortelainen \& Järvi, 2014). This study explores a service delivery network within a service ecosystem of healthcare actors. The unit of analysis is a service delivery network of eight different organizations (small and medium-sized enterprises [SMEs], insurance companies, large corporations and healthcare providers) that aim to jointly create preventive healthcare solutions using a human-centred personal data management approach.

This paper is structured as follows. The background for this study is presented in Section 2, focusing on personal data as well as on the benefits and challenges of data. Section 3 introduces the research approach of this study. In Section 4, the authors present the results of a case study. Section 5 discusses the implications, limitations and further research avenues of the study. Finally, Section 6 concludes the paper.

\section{Background}

\subsection{Personal data}

The amount and availability of data is staggering in these modern times. One of the most rapidly growing categories of data is so-called personal data, which can generally be understood as information pertaining to an individual's personally identifiable data (European commission, 2016). The average individual has massive amounts of personal data stored in many different locations. This data could bring in vast opportunities for service providers and benefit the individual. However, most of that data is inaccessible: the data is owned and operated by the respective organizations that have harvested it. For many organizations, the harvested data is considered either a competitive advantage that is not to be shared or it contains sensitive personal data that is not to be shared (Ctrl-Shift, 2014). Personal data is an important resource for value creation among companies and society. The value of personal data is large and growing (Schwartz, 2014), and is expected to grow into a market worth nearly $€ 1$ trillion by 2020 in Europe alone (Ctrl-Shift, 2014; European commission, 2016). Organizations in both public and private sectors have long been collecting personal data to gain insight, efficiency and competitive advantage (Ericsson, 2013), for example, by removing information asymmetries and facilitating efficient transactions (Facebook, 2014).

In Europe, the General Data Protection Regulation enforces the security and transparency of data, and effectively forces organizations to give back personal data in a digital form to individuals upon request (European commission, 2016). These regulations may increase the overall costs of harvesting and keeping information about individuals but will also present huge business opportunities in the form of newly available data resources (Ctrl-Shift, 2014; Poikola, et al., 2014). Poikola et al. (2014) argue that the availability of wide-ranging personal data will 
revolutionize all industries and aspects of society. Organizations utilizing personal data can better optimize resource allocation, create novel service paths and provide personalized services (Ctrl-Shift, 2014).

The healthcare sector cannot afford to overlook the opportunities enabled by the use of technology (i.e. data) with the overall demand for healthcare services continually rising. Researchers widely acknowledge the impact of the extensive use of technology - data in particular - in predicting, preventing and managing health conditions (Collins \& Varmus, 2015; Baldwin, 2010; Pinho, et al., 2014). In the US healthcare sector alone, big data and user-generated content are seen to generate approximately $\$ 300$ billion a year in value, with around 0.7 per cent annual productivity growth (Pujol, et al., 2016).

\subsection{Networks, ecosystems, and service delivery}

The preventive healthcare actors have a shared mission of preventing illnesses. The overall physical condition of a single individual is dependent on various aspects: for example, eating habits, exercise, mental health, and health conditions. These are all interrelated, but a medical doctor is rarely aware of how the patient really eats and exercises, and a personal trainer rarely consults the customer's doctor or dietitian to attain a holistic picture of the customer's current state of health. Thus, while there are services to attend to each aspect of an individual's overall health, they are separate and rarely, if at all, communicate with each other. However, from the customer's perspective, these services are a connected service entity, focused on maintaining the customer's good health.

Companies are increasingly more connected, and no company can provide their services without the help of other organizations in their network. The locus of value creation has moved from within company boundaries to value being jointly created between various actors within the networked market (Nenonen \& Storbacka, 2010). This interconnectedness is referred to with different names for different purposes. While criticized by many scholars (Vargo \& Lusch, 2004) for its lack of wider perspective, in industrial contexts, the value chain is still widely used. The value chain describes the whole process of a product or service from conception to manufacturing to delivery to consumption to disposal. Of course, the real world is never that simple, all models are merely necessary simplifications of real life. Networks for instance related to R\&D and innovation has been widely researched and characterized by uncertainly during the past decade (Arrow, 1974; Möller \& Rajala, 2007; Henttonen, 2008; Hurmelinna-Laukkanen, et al., 2012). Such networks have been exploited from the perspective of independence, stability, dynamism, collaboration, competition, formality, management requirements as well as innovation orchestration roles and practices (Henttonen, 2008; Moenaert, et al., 2000; Hurmelinna-Laukkanen, et al., 2012; Pikkarainen, et al., 2017). Additionally, the innovation network studies have been increasingly done focusing on the organizational interaction and orchestration that is happening in different networks and ecosystems (Dhanaraj \& Parkhe, 2006; Laperche, et al., 2008; Reypens, et al., 2016). Although networks have attracted much managerial and academic interest, it is still not clear for managers how to deal with innovation networks having variety actors co-creating and capturing value (Hurmelinna-Laukkanen \& Nätti, 2018). 
The ecosystem as a concept (Lehto, et al., 2013; Moore, 1996) has risen as an approach to explaining the complexity of different business entities' interconnectedness. For different contexts, there are further defined ecosystems, such as industrial ecosystem, innovation ecosystem, knowledge ecosystem, and business ecosystem (Smorodinskaya, et al., 2017). These ecosystems have common elements defining them: actors, interconnectedness, complex networks of relationships, and resources, all of which are combined and integrated in a unique manner (Valkokari, 2015). Moore (1996) describes business ecosystems as a group of interdependent, interconnected and collaborating customers, agents, channels and sellers of common services. Business ecosystems help companies to generate end-user value and create new markets that single companies could not do by themselves (Adner, 2006). Companies that are part of ecosystems can better develop their capabilities and utilize resources. To be successful, business ecosystems need keystone companies that offer platforms, tools and technologies that support the other players' performance in the ecosystem and share value with other participants (Iansiti \& Levien, 2004; Valkokari, 2015; FitzPatrick, et al., 2015). A healthy ecosystem not only assembles the actors who contribute to the system, it also provides a mechanism for building relationships, trust and other intangibles between the actors and entities within (Jackson, 2015). Ideally, a well-managed ecosystem is robust towards external disruptions and capable of increasing meaningful diversity (Iansiti \& Levien, 2004). It is particularly relevant for start-ups to be part of ecosystems (Zahra \& Nambisan, 2012). Clarysse, et al. (2014) discovered that the success factors for knowledge and business ecosystems look very similar: diversity of organizations, and an anchor/keystone actor. Still, et al. (2016) explored the innovation and business ecosystems of companies in an emerging market of fintech, and found that an individual company may have differing roles in the respective ecosystems, but that the types of interaction and logic of action may also overlap between the ecosystems. This goes to show that innovation managers need to consider interactions in many types of ecosystems.

However, as concepts, networks and ecosystems remain ambiguous and are too often used interchangeably in the literature (Chesbrough, 2007). In service-dominant logic, the network is regarded as one component of a larger service ecosystem, wherein the attention is on the systemic nature of the relationships of the actors (Akaka, et al., 2013; Mele \& Della Corte, 2013). For the purposes of this study, we need a concept that describes interconnected organizations that work to fulfil the goals of a single customer in a specific domain. Tax, McCutcheon and Wilkinson (2013) introduced a suitable concept to describe such network: the service delivery network (SDN), which is defined as two or more organizations that, in the eyes of the customer, are responsible for the provision of a connected overall service experience. Ecosystems are used in this study to describe the larger networked nature of the modern business environment of which SDNs are a part of.

The increasingly networked and connected world has led to fragmentation of service delivery. The benefits afforded by specialization caused by digitalization and technological progress has increased organizations' reliance in complementary service providers (Ostrom, et al., 2015). Data has empowered customers to act as resource integrators, selecting desired service bundles to better suit their individual needs. The value of data is recognized in widely in various industries (Furtado, et al., 2017), but how data can be capitalized remains one of the most pressing topics among academics and practitioners, especially in healthcare sector (Lee, 2018; Ratia, et al., 
2018). Thus, data-driven ecosystems and networks have become an important area of research (Lim, et al., 2017; Ostrom, et al., 2015).

To make a holistic service for preventive healthcare, the actors must form an organizational network, which will jointly provide a connected series of services for the individual customers to upkeep their health. The structure of such network needs to be organized in a way that integrated resources will be focused on addressing the needs of the end customer (Clarysse, et al., 2014), leading to a solution for an end customer in a way that each actor is responsible for a specific component of the overall solution.

\subsection{Using data to advance preventive healthcare}

\section{Data as a resource that enables actions}

Companies have noticed that self-tracked data may provide business opportunities. Many companies provide self-tracking devices, wearable sensors, and mobile applications that individuals can use to measure and compare data to change their behavioural activity. With better access to personal data as a resource, organizations can optimize resource allocation, create solution pathways and provide personalized solutions (Poikola, et al., 2014). Some examples of these types of solutions are health and wellness apps, that can track information about food consumption, sleep patterns, blood chemistry, moods, menstrual cycles, heart rates and stress levels (Sharon, 2015). By utilizing personal data, it is possible to improve consumer experiences by understanding individuals' needs and preferences, usage patterns and behaviour. This kind of personalization can make preventive healthcare solutions more relevant, easier and quicker. This, in turn, can also lead to increased loyalty. With relevant information about the individual, a service provider can "offer the right services, at the right price, through right channels at the right time" (Ericsson, 2013). The benefits of data in business are obvious. In fact, many businesses that fail to align themselves with data-driven practices risk losing a critical competitive advantage, market share and revenue. Therefore, effective data utilization affects not only competitiveness but also survival in tight market competition (Brownlow, et al., 2015). Quite often, the actors of an ecosystem operate around a focal company that is linked to a platform (Valkokari, 2015; Iansiti \& Levien, 2004). Networks often arise around a central node - for example, a shared platform - making it possible to collect and share the data, which therefore has an impact on data-driven business creation. There are many examples of players that have created new markets using data and platforms in their ecosystems, for example Apple, Google, Amazon and Airbnb. FitzPatrick, Varey, Grönroos and Davey (2015) introduce the concept of a platform of co-creation that enables and supports direct interactions among those that participate in the value co-creation process.

\section{Data as resource that hinders actions}

One challenge in the use of data as a resource is data quality. Low quality data does not bring end-user value. Low quality data can result in misleading analyses, and lead to wrong decisions (Redman, 2015). The benefits of fixing quality of data coming from self-tracking can be enormous for companies. Low quality data presents an inherent risk, as it can cause the reputation of a company to plummet in the eyes of the end-users. Often companies realize the 
opportunity associated with data but fail to determine a specific target for their data acquisition and analysis. By targeting a pre-determined outcome, the business can retain its focus on a desired and realistic goal, and reduce any unnecessary waste of resources (Brownlow, et al., 2015).

The actors of the service delivery network should carefully think about the content and purpose of the collected data to avoid enormous data acquisition and analysis costs. The end data is useless, if it does not bring added value to the end-user (Redman, 2015). There will be questions raised related to the legal limits of the data collection, storage and usage. The privacy of data becomes an issue for a company whenever the data it processes relates to people. The legality of data protection and sharing is strongly dependent on the context in which it is used (Otjacques, et al., 2007). In our study, the context of healthcare raises privacy issues to an even bigger focus.

\section{Factors that enable change}

Many reasons are driving companies towards the co-creation of preventive healthcare solutions. First, populations are aging rapidly. For instance, the population of the US is predicted to double by 2050. Second, the costs of medical care and especially chronic diseases are increasing, even by 7.3 per cent by 2050 (Kim, et al., 2014). The model of targeted, preventive and participatory healthcare has been identified as a potential solution for the crisis of public healthcare systems (Norris, 2012; Flores, 2013).

Electronic medical record systems improve the coherence of the care process (McDonald, 1997). The large amount of data in the systems, gathered from each individual patient, could be used to improve and personalize preventive healthcare services when it benefits the individual. The challenge is that the medical information is typically under very strict data protection laws and is in different systems with various interfaces (McDonald, 1997). In some countries, such as in Finland, the government has built national databases that can be regarded as an individual's data storage for personal medical and self-measured data (Kanta, 2016).

Data is the key resource in co-creating preventive healthcare services (Ratia, et al., 2018). Due to the nature of sensitive personal data, companies that need access to it, need to collaborate. Companies that are part of such networks can better develop their capabilities and utilize resources. Participation in data-driven networks helps companies to i) differentiate themselves from competitors (Wang, 2012), ii) create new end-user value (Huhtala, 2018) and iii) scale their business (with the help of the ecosystem) in a way that a single company could hardly manage on its own (Adner, 2006). In this context Vargo and Lusch $(2004,2008)$ use the term competitive advantage and strategic benefit (2016) to capture the beneficial impact of the operant resources.

\section{Factors that hinder change}

Recently, there have been critical discussions about self-tracking for health in the social sciences literature (Lupton, 2012; 2013; 2014; 2015; Morozov, 2013; Whitson, 2013; Ruckenstein, 2014). These critical analyses articulate a number of concerns regarding the social, cultural, political and ethical implications of personal data collection and self-tracking, and the move toward more personalized healthcare (Sharon, 2015). Zainuddin, Tam and McCosker (2016) investigate the 
phenomena of emerging, technologically facilitated value self-creation solutions in the healthcare sector. One example of a technology-driven health solution is blood glucose monitoring, in which a person monitors his or her blood glucose several times a day. In this context, consumers are collaborators and value receivers in the value co-creation process. In this context the organizations become value facilitators at the backstage of an overall service exchange (Zainuddin, et al., 2016).

Companies should avoid the situation in which only some of the personal data is shared with the permission of individuals (Redman, 2015). It might be impossible to prevent this from happening, since many companies still consider keeping data to themselves their competitive advantage. However, every actor in the service delivery network would be able to make better services for the end customer by using more and better data provided through collaboration.

The benefits and challenges and the related drivers of data-driven service delivery networks are summarized in table 1.

\section{Research Methodology}

The aim of this paper is to understand what the success factors of a data-driven service delivery network are in the context of preventive, personal data driven service creation.

Our research strategy focused on understanding the studied phenomena within single settings (Eisenhardt, 1989). The benefit of the case study approach is that it is a way to increase understanding and to get closer to the theoretical constructs related to the evaluated phenomena (Eisenhardt \& Graebner, 2007; Siggelkow, 2007, p. 22).

\subsection{Context}

Theoretical sampling means that cases are selected for the study because they are particularly suitable for explaining the relationships and logic among constructs (Eisenhardt \& Graebner, 2007). Organizations that both worked in a specific role in preventive healthcare and had an interest in using human-centred data management approach were given priority in the case selection criteria. To gain a deeper understanding of the various actors involved, data was collected from established stakeholders and start-ups in healthcare, wellness, insurance, tech and application providers and in the telecommunication sector. Some of the selected companies - for example two SMEs, an occupational healthcare provider and an insurance company - already worked together in the same service network, co-creating value for their customers. The rest of the selected players were willing to participate in the service delivery network, bringing additional value to the future customer scenario.

\subsection{Data collection and analysis}

The theory building case studies are typically done with multiple data collection methods in which the interviews, observations and archival sources are common data collection sources. Multiple 
Table 1. An overview of the benefits and challenges of extant data-driven service delivery networks

\begin{tabular}{|c|c|c|}
\hline Author (Year) & Definition of benefits and challenges & Related drivers \\
\hline \multicolumn{3}{|c|}{ Category 1: Data as a resource in data-driven service delivery networks } \\
\hline $\begin{array}{l}\text { (Sharon, 2015; } \\
\text { Zainuddin, et al., } \\
2016)\end{array}$ & $\begin{array}{l}\text { Self-tracking services, devices, wearable sensors, and } \\
\text { mobile applications are used as a resource to make it } \\
\text { possible for end users to collect, measure, and use } \\
\text { data to change their behavioural activity }\end{array}$ & $\begin{array}{l}\text { Value } \\
\text { self-creation }\end{array}$ \\
\hline $\begin{array}{l}\text { (Valkokari, 2015; } \\
\text { FitzPatrick, et } \\
\text { al., 2015; } \\
\text { Redman, 2015) }\end{array}$ & $\begin{array}{l}\text { A shared platform that makes it possible to collect } \\
\text { and share the data in service delivery networks }\end{array}$ & $\begin{array}{l}\text { A platform of } \\
\text { co-creation }\end{array}$ \\
\hline (Redman, 2015) & $\begin{array}{l}\text { A network or an institution uses the wrong data and } \\
\text { does not bring added value to the customer, losing } \\
\text { their good reputation in the market }\end{array}$ & $\begin{array}{l}\text { Customer value } \\
\text { not achieved }\end{array}$ \\
\hline $\begin{array}{l}\text { (Adner, 2006; } \\
\text { Vargo \& Lusch, } \\
2015)\end{array}$ & $\begin{array}{l}\text { The service delivery network generates end-user } \\
\text { value and creates new markets that single companies } \\
\text { could not generate or create by themselves }\end{array}$ & $\begin{array}{l}\text { New market } \\
\text { creation }\end{array}$ \\
\hline (Redman, 2015) & $\begin{array}{l}\text { The content and format of the collected data are not } \\
\text { systematic, which leads to enormous data } \\
\text { acquisition and analysis costs }\end{array}$ & $\begin{array}{l}\text { Data analysis } \\
\text { costs }\end{array}$ \\
\hline $\begin{array}{l}\text { (Wang, 2012; } \\
\text { Vargo \& Lusch, } \\
\text { 2004; 2008; 2016) }\end{array}$ & $\begin{array}{l}\text { Actors use data as a resource to differentiate a } \\
\text { business from that of others, bringing competitive } \\
\text { advantage with the resources in the network }\end{array}$ & $\begin{array}{l}\text { Competitive ad- } \\
\text { vantage/strategic } \\
\text { benefit }\end{array}$ \\
\hline (Adner, 2006) & Use of data is a resource to scaling up the business & $\begin{array}{l}\text { Business } \\
\text { scalability }\end{array}$ \\
\hline
\end{tabular}

Category 2: Challenges to overcome in data-driven service delivery networks

(Ruckenstein, Ethical concerns related to data usage Ethical rules 2014)

(Redman, 2015)

The quality of the data

Data quality

(Otjacques, et

Legal limits, the privacy of the data collection,

Legal rules \&

al., 2007) storage and usage

regulations

cannot be

followed

(Redman, 2015) Some companies in the same service delivery

Data in internal network still keep customer data in internal silos silos 
data collection provides the evidence that leads to the stronger substantiation of constructs (Eisenhardt, 1989). In this study the meetings, workshops, interviews, observations and other material available from studied organizations were used as a source for analysis (Eisenhardt, 1989). A three-phased approach was used in this study (Figure 1).

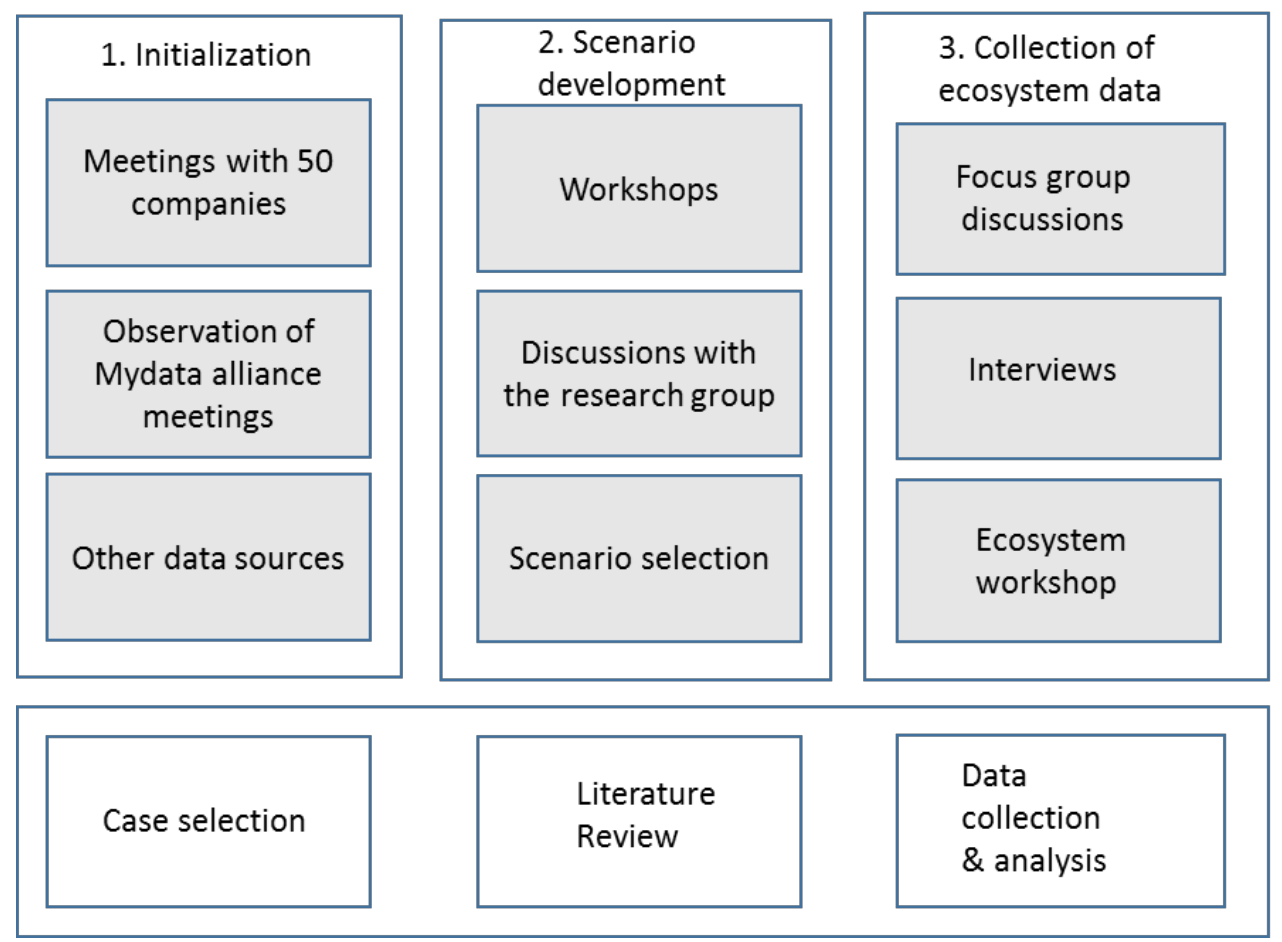

Fig. 1. The research process

The scenario technique is a qualitative method that makes it possible to describe complex situations that may happen in the future. With the rise of strategic and management consultancies the scenario technique has been used as consulting and evaluating tool there (Fink, et al., 2004). According to Fink et al. (2004) the scenario technique covers three steps: i) analysis of the scenario field to find descriptors and their cross linking, ii) the selection of several scenario alternatives and iii) the final scenario development (Muskat \& Backman, 2012). In the first step of our study, the initialization step of our study the researchers had meetings with 50 different company representatives in the health sector during a six-month time period. Additional data for the service delivery network was collected from the Internet, newspapers, social media and observations that were made in MyData alliance meetings (https://mydatafi.wordpress.com/), in which most of the interviewed companies participated regularly.

We selected a case, which allowed us to understand the benefits and challenges of the data-driven service delivery network from different perspectives. Where possible, we also aimed to identify how prevalent each issue was across the case studied. The selected case (a data-driven service delivery network) involves organizations that are part of a network, targeting to make services for the preventive healthcare domain. In the third phase of our study, several scenario alternatives were identified and further developed. The opportunities in each scenario were further explored 
in two workshops with the research team, based on the collected industrial experiences. For this study, a single end-user scenario was selected for presentation to the interviewed companies. (See Appendix 2)

After the scenario development, a literature review was conducted focusing on the barriers and benefits of the service delivery network. The focus group discussions were conducted between March and May 2016 with the directors of two SMEs, the directors of two insurance companies, a doctor and two nurses from a private healthcare company and two directors of large corporations. The literature review about the benefits and challenges worked as a baseline for the questionnaire that was used in the focus group interviews. In the next phase, we conducted eight in-depth interviews with senior personnel of the selected actors of the service delivery network. A future end-user scenario narrative was presented to each of the interviewees of the companies after a few basic questions. The used scenario approach supports the argument of Vargo and Lusch (2016) that "actors cannot deliver value but can participate in the creation and offering of value propositions." In our case, the value proposition (a holistic preventive healthcare service continuum) was then discussed and updated in both focus group discussions and interviews with each company.

The data collection process was finalized with a workshop in which all the service delivery network actors were brought together to discuss the benefits and challenges, as well as the updated scenarios. In the data analysis, statements were identified, sorted and structured to identify benefits and challenges that may appear in data-driven service delivery networks. The analysis was conducted with an analysis technique described by Eisenhardt (1989) in which domains (i.e. the benefits and challenges generated from literature) were used to look for within-group similarities coupled with intergroup differences. During the data analysis process, we independently analysed and encoded all the transcribed material using benefits and challenges that emerged from the literature as starting categories for the conducted analysis.

\section{The success factors in data-driven service delivery networks}

\subsection{Benefits of data in data-driven service delivery networks}

\section{Service complementarity between actors via data sharing \\ \# Creating value and scaling business via the data availability}

The healthcare providers mentioned that it would be an interesting opportunity for them to work as a channel for other actors to get access to customers. This would help both SMEs and healthcare providers to create proper measurements and more holistic services for individuals.

The data availability will enable us to create services based on the real needs of a person [...] If someone has a medical condition there could be a service that tells when to go to a doctor if something happens in terms of eating or feelings. (B, see Appendix 1)

If we know more, we can focus on where the problem really is. I mean that if a person is overweight, but his cholesterol level is fine, we should pay attention to the sleeping and 
mental health situations. These are the kind of things that we could figure out using the data. (Nurse, healthcare provider)

Thus, "Data will make it possible to produce both individual and group-level focused services, which open business opportunities." (Doctor, healthcare organization B)

\section{Better and more personalized services}

Two of the interviewed SMEs $(\mathrm{A}, \mathrm{H})$ were also looking at data availability as a way to create value for their end customers through novel services. It was mentioned in the interviews that

"the most important thing in data availability is the possibility to show an individual his or her weaknesses and strong areas. [...] Certain self-measured values (blood glucose and blood pressure) could be added as additional features to the service, which could provide more meaningful analysis possible to do measurement at home and work" (Director) (A).

The interviews outlined that many future actions in the private healthcare sector will be more and more focused on preventive healthcare and especially on early signals about an individual's health trends and services supporting wellness. In this context, personalization was mentioned (in all together eight interviews: A-I) as a key benefit in the data-driven service delivery network, used to differentiate a business.

For example, it was noted by a doctor for a healthcare provider (B) that

"in the future, data from several sources (workplace activities, health checks, electronic health questionnaires) could be connected and utilized when providing occupational wellness or health services for companies, which are based on company-specific profiles. For example, some SMEs already have service offering solutions for work organizations to support preventive wellness improvements among their employees on a group level. In the future scenario, beneficial information from an individual could be about blood glucose, PEF, weight etc."

Integrated, well-presented data was identified as valuable assets, also for personal trainers. For example

"[for a personal trainer] receiving data directly from a medical centre would be a great advantage since a person might not know how to describe his or her current state of health sufficiently or might exaggerate" (Personal Trainer) (D).

In fact, personal data could make it easier to match an individual with a compatible personal trainer. Sharing the personal-training accumulated data for the individual is seen as a good idea, since it could help others help the said individual.

Insurance companies identified the service delivery network and personal data scenario as an enabler that will

"give more real-time information for a customer, added value for the customers comes through new services, which are built on data and information" (F).

In fact, both interviewed insurance companies pointed out that a data-driven business scenario and richer data availability are ways to gain a better capability to understand what the customers really want and need and therefore to create better personalized services. 
"Better collaboration between health and service providers will help us to give better solutions to our customers. Especially in those cases in which the customer needs to contact many organizations." (C)

The better visibility of personal data was identified both as competitive benefit and phenomenon which is raising new ways to collaborate and share revenue:

"Business is beginning to be so networked and linked that no one is expert in all areas. We must to look for data and new types of profit-sharing business models" (A).

The representatives from large companies $(\mathrm{G}, \mathrm{I})$ commented that better data analysis could help players to create services that are really valuable for individuals. In the interviews, the MyData approach was seen as a great way to generate new businesses.

A personal trainer company (D) saw data-driven business as a way to save time, especially in the early phase of training. It was noted that profiling a person based on data would help them to prepare better for the first meetings and to plan better services since background questioning is typically really time consuming. Additional value for a personal trainer could be to see what the customer has done outside of their training time, for example to see if the established routine has been followed.

\section{\# Personalization can be used as a resource to differentiate a business and to mo- tivate people to share more data}

Four of the interviewed actors (from A, H, D, I) mentioned that personalization could be a way to motivate people to share more data. The director of an SME (A) noted:

"The knowledge that you get a better health service by sharing your data is actually motivating people to share more data [...] people share data if they trust their nurse or personal trainer". Being able to see one's progress can be seen as a way to motivate people to do more preventive healthcare actions. "An individual might be more inclined to share data for personalized services" stated the director of a personal trainer organization (D).

\section{Improved efficiency via cost and time savings}

\section{\# Data can be used as a resource to get cost and time efficiency from a professional's perspective}

Across the eight cases studied, it was found that data-driven services could bring additional value for the different professionals. Cost and time efficiency were mentioned as benefits of data-driven business by four interviewees. The director of an SME (A) noted:

"The target is that the individual owns his or her data but could get better preventive healthcare services when the data is borrowed by a doctor or a nurse".

It was noted that the behaviour of people has changed a lot in the past decade. A nurse for a healthcare provider (B) observed that

"Nowadays people are bringing data to a doctor's appointment without request. They are showing their heart rate data, for example from tracking solutions [...] Providing preinformation before the appointment saves time. The doctor does not need to count some values manually and enter information from different papers into a computer". 
Insurance companies mentioned that the data-driven business approach would help them to decrease insurance costs. Director of an insurance company (F) noted:

"For example, if a customer is active and the risk of getting sick is identified to be lower, health insurance cost could decrease".

\subsection{Challenges to overcome in data-driven service delivery networks}

\section{Technology issues}

\section{\# Data reliability}

Data reliability was mentioned as a challenge by four of the interviewed companies. From the individual perspective it was noted that

"If the person is sick and he or she needs to check his or her weight or temperature, it is important that the information is absolutely right. People understand quite well the basic measurements. It becomes more difficult when you start to measure more sophisticated things, for example things that are not so clear for people - then it is not so clear what the meaning of the data is."

The reliability aspect was not so big a risk for those SMEs that do not currently have medically certified solutions. However, it was noted by interviewees from both SMEs that medical certification might be needed in the future in order to combine the data in coherent manner.

"If the system gives medical advice the data has to be reliable." observed the director of two SMEs $[\mathrm{A}, \mathrm{H}])$.

It was observed by personal trainers that

"Personal data is perceived to be more reliable if it is automated, not input by an individual, since individuals tend to give better impressions of themselves and can misremember, or disregard, something important".

One reliability challenge mentioned (by an interviewee from D) was also the question of if we can trust our medical data to be handled by foreign operators on the outside of the service delivery network.

\section{\# Standard interfaces are missing, and data is in the wrong format}

The data usage and transformation were clearly seen as an added value for both individuals and organizations in service delivery networks.

"If the data usage is not possible between the services, we are actually decreasing the value of the service." stated the director of a large corporation (I): "We should build system in which the data follows a person one way or another."

There are many examples where a person has been visiting some healthcare organization for 10 years and then moves and starts to visit another healthcare organization. Can the person move his or her personal data from place $A$ to place $B$ if he or she has some treatment that demands continuous monitoring? If the new health provider cannot use anything that the 
person has been collecting for 10 years, the person is likely to be ready to exert some time and effort to transfer the data. (Director, insurance company $\mathrm{C}$ )

However, the lack of standard interfaces for receiving data was a challenge encountered by all the types of organization studied.

"One clear challenge in our business ecosystem is the poor data interfaces - all the knowledge is in internal silos. We need to exert much effort to collect all the data together"

noted a nurse working for a healthcare provider. "How can we get working interfaces between the services. $[\ldots]$

We need someone to tell us what interface to use in order to move the data to healthcare and what interface to use to move the data across to a personal coach. We need standards to help us."

stated the director on an SME. "There is a challenge with the standards. What will the winning format be that transforms the data? If we think of any domain, we still have such old-fashioned systems and it means that there will be technical problems if we try to move the data from one service to another" noted the director of an insurance company $(\mathrm{H})$.

According to the interviewed director of an SME, the regulations (European commission, 2016) are telling companies that the data they give back to the individual should be in a machinereadable format. The challenge, however, is that there is no agreement on the format of the data because the requirements for it vary actor by actor.

"All the services are a bit different. They have a different perspective on the data regarding what to do with it and how to enrich it." (H).

Although the common interfaces were seen as a benefit, the business value of the data integration was not concrete enough for all the interviewed SMEs to make the effort to make better data interfaces.

"We are not making that type of data interfaces before there is some business case and business benefit for us because it would require resources from us to make such interfaces." $(\mathrm{H})$.

In Finland the Kanta database was seen as a one solution for data transferral. It was however realized that

"Kanta does not offer any real-time data. The stable data is only a small part of the whole value for the individuals and health professionals that could be gained from the data" noted director of a large corporation (I)

The lack of standard interfaces was also a problem for potential data operator, platform players.

"We do not have standards. Even if you had an operator, you have to save the data in some format. [...] In order to use it you need a similar format and a structure so that the data could be converged from one system to another. [...] We need all kinds of filters and converters and it might be quite a technical challenge to make it happen." (G). 


\section{\# Service interfaces must be easy to use}

Simplicity was mentioned as a key for successful service creation in three of the analyzed organizations. The director of an SME mentioned that

"The services should be easy to use. This means that you push one button and your data is available for healthcare providers and you push another button and your data is in the use of a personal coach. But if the data transformation demands any more than that from an individual it will never happen."

And another director of an SME (H) noted that the

"Methods of self-measurement must be as simple as possible to reach all potential users. Simple visualization is must for an end user."

Wellness and health-related information (e.g. current state and target state) should be delivered for the individual through visualizations, not through numeric values. [...] The companies should show positive information using graphs; especially young people want everything to be shown very simply and briefly. One typical challenge in self-diagnosis can also be that too much negative data is shown to the person. (B)

When there is much knowledge available, people start to use the knowledge to do selfdiagnosis and often get lost. It is great that we collect knowledge but often we are just collecting negative information. [...] Why do we not collect information on how strong you feel? On the happy moments of your life? Often people just get angry when they do not get help when they need it. Often people start to self-diagnose themselves and stop using medicine because they get information about its potential side-effects from the internet. (Nurse, healthcare provider B)

\section{Governance issues}

\section{\# Missing roles in the current service delivery network}

Across four companies, it was found that there are missing roles in the business ecosystem that are actually hindering data-driven business development in the domain of preventive healthcare.

"Consumers need someone who can take responsibility for their wellbeing during their whole life. --- The insurance companies cannot take this role because people are so suspicious of insurance players. They think that we just want to decrease our costs. --- This could be some private healthcare provider or public healthcare actor. Public service providers have the need, but not the resources, to make this happen. There will be some actor who will take this role and integrate the needs of other actors. Or it may be that the employee organizations take this role, but for now this seems to be a missing role in our business ecosystem." (F)

One missing player in the ecosystem seems to be an operator who is making sure that the individual's data is safe and under the control of individual. (Director of a large company [G]) 


\section{\# Unclear revenue model}

When the roles in business ecosystems are not clear, it is unclear for SMEs to whom should they actually be selling the new services.

"No matter if we sell a consumer service or company service, the end results are often very similar. The key question in the future preventive healthcare scenario in which the individual owns his or her data, is who will buy the end service? Is it an individual or is someone going to buy it for the individual? Is it the employee's organization, private healthcare players, the public sector or an insurance company?" Director (A).

Insurance company representatives mentioned that

"it would be ideal that each person would have their own personal trainer. But it is not possible for insurance companies to buy everything."

The director of an insurance company reminded us that the individual who is helped should also be ready to buy something for the future wellbeing services.

"The individual's readiness to buy is the basic question that is now hindering the business development in the preventive healthcare domain." stated the directors of an insurance company $(\mathrm{C}, \mathrm{F})$.

From an individual perspective it was noted that personal data could also be valuable assets to sell to different actors in the future.

"Perhaps individual could ask his own data from actor $A$ and sell it to actor B. This would be added value that is not existing now" stated the director of a large company (I).

\section{\# The wrong target audience}

It was mentioned by three interviewees that one of the biggest challenges of data-driven service delivery networks in the preventive healthcare domain is that it is difficult to reach the audience that would most benefit from the created services.

"We can easily make services for the active engineers that get excited about the data. The challenge is how we can make solutions based on data in a way that it is motivating for normal people. That is our usability and commercialization challenge" observed the director of an $\operatorname{SME}(\mathrm{H})$.

The problem is that those people who already are active, who are exercising, who are eating well are the people who are using most of the preventive services. The segment of the people who need the services most are not really using them. (Director, insurance company C)

\subsection{A summary of the findings}

A key output from this study is a set of success factors to be considered in data-driven service delivery networks. These are discussed throughout this article and summarized in Table 2. 
Table 2. A summary of success factors

Benefits of data and related success factors in data-driven service delivery networks

\begin{tabular}{|c|c|c|}
\hline Benefits & Success factor & Related literature \\
\hline \multicolumn{3}{|c|}{ Service complementarity between actors via data sharing } \\
\hline $\begin{array}{l}\text { \# Creating value and } \\
\text { scaling business with the } \\
\text { available data }\end{array}$ & $\begin{array}{l}\text { Healthcare providers work as } \\
\text { customer acquisition channels } \\
\text { for complementary service } \\
\text { providers. The data, as a } \\
\text { resource, will enable different } \\
\text { players to create services } \\
\text { based on the real needs of a } \\
\text { person }\end{array}$ & $\begin{array}{l}\text { Self-tracking services, devices, } \\
\text { wearable sensors and mobile } \\
\text { applications are used as a } \\
\text { resource to make it possible } \\
\text { for end users to collect, } \\
\text { measure and use data to } \\
\text { change their behavioural } \\
\text { activity (Sharon, 2015; } \\
\text { Zainuddin, et al., 2016) } \\
\text { The use of data is a resource } \\
\text { for scaling up the business } \\
\text { (Adner, 2006) }\end{array}$ \\
\hline
\end{tabular}

\begin{tabular}{|c|c|c|}
\hline $\begin{array}{l}\text { \# Personalization can be } \\
\text { used as a resource to } \\
\text { differentiate a business } \\
\text { and to motivate people to } \\
\text { share more data }\end{array}$ & $\begin{array}{l}\text { Data can be used as a resource } \\
\text { to create personalized services } \\
\text { which make it possible to get } \\
\text { more personal data and } \\
\text { motivate people to do more } \\
\text { preventive healthcare actions }\end{array}$ & $\begin{array}{l}\text { The use of data as a resource } \\
\text { to differentiate the business } \\
\text { from others, bringing } \\
\text { competitive advantage with } \\
\text { the resources in an ecosystem } \\
\text { (Wang, 2012; Vargo \& Lusch, } \\
\text { 2004; 2008) }\end{array}$ \\
\hline \multicolumn{3}{|c|}{ Improved efficiency via cost and time savings } \\
\hline $\begin{array}{l}\text { \# Data can be used as a } \\
\text { resource to get cost and } \\
\text { time efficiency from a } \\
\text { professional's perspective }\end{array}$ & $\begin{array}{l}\text { The analysed data will work } \\
\text { as a resource helping } \\
\text { professionals to focus on the } \\
\text { right actions and to save } \\
\text { wasting their time on } \\
\text { irrelevant actions }\end{array}$ & $\begin{array}{l}\text { A new benefit appeared from } \\
\text { the case analysis }\end{array}$ \\
\hline
\end{tabular}


Challenges to overcome and related success factors in data-driven service delivery networks

\begin{tabular}{|c|c|c|}
\hline Challenges & Success Factor & Related literature \\
\hline \multicolumn{3}{|l|}{ Technology issues } \\
\hline $\begin{array}{l}\text { \# Data reliability \& } \\
\text { quality }\end{array}$ & $\begin{array}{l}\text { Data collection should be } \\
\text { made as automatic as } \\
\text { possible: the data that is } \\
\text { inserted by people is often not } \\
\text { reliable because people do not } \\
\text { want to tell the truth }\end{array}$ & $\begin{array}{l}\text { Quality of the data (Redman, } \\
2015 \text { ) }\end{array}$ \\
\hline $\begin{array}{l}\text { \# Standard interfaces are } \\
\text { missing and data is in } \\
\text { wrong format }\end{array}$ & $\begin{array}{l}\text { The standard interfaces for } \\
\text { data transformation are } \\
\text { urgently needed }\end{array}$ & $\begin{array}{l}\text { Some companies in the same } \\
\text { service ecosystem still keep } \\
\text { customer data in internal silos } \\
\text { (Redman, 2015) }\end{array}$ \\
\hline $\begin{array}{l}\text { \# Service must be easy to } \\
\text { use and supportive }\end{array}$ & $\begin{array}{l}\text { Attention must be paid to } \\
\text { service design: unsupportive } \\
\text { user interface and complex } \\
\text { data presentation deter } \\
\text { customers }\end{array}$ & $\begin{array}{l}\text { Using service design to } \\
\text { encourage the use of data in } \\
\text { service advancement (Ostrom, } \\
\text { et al., 2015) }\end{array}$ \\
\hline \multicolumn{3}{|l|}{ Governance issues } \\
\hline $\begin{array}{l}\text { \# There are missing } \\
\text { partners and a payment } \\
\text { structure in the current } \\
\text { service delivery network }\end{array}$ & $\begin{array}{l}\text { The responsibilities and } \\
\text { payment structure need to be } \\
\text { clarified in preventive } \\
\text { healthcare service delivery } \\
\text { networks }\end{array}$ & $\begin{array}{l}\text { Actors of an ecosystem often } \\
\text { operate around a facilitating } \\
\text { anchor/keystone company } \\
\text { that is linked to a platform } \\
\text { (Valkokari, 2015; Iansiti \& } \\
\text { Levien, 2004) }\end{array}$ \\
\hline \# Unclear revenue model & $\begin{array}{l}\text { A clear business model is a } \\
\text { requirement for the SDN }\end{array}$ & $\begin{array}{l}\text { Business model is essential to } \\
\text { articulate the changes wanted } \\
\text { or needed by the firm (Keen \& } \\
\text { Qureshi, 2006) }\end{array}$ \\
\hline $\begin{array}{l}\text { \# The wrong target } \\
\text { audience }\end{array}$ & $\begin{array}{l}\text { The future services should be } \\
\text { targeted to normal people who } \\
\text { currently are not interested } \\
\text { about their health issues - not } \\
\text { only to people already active } \\
\text { and interested in their health }\end{array}$ & $\begin{array}{l}\text { A new challenge appeared } \\
\text { from the case analysis }\end{array}$ \\
\hline
\end{tabular}




\section{Discussion}

Some of the success factors for data-driven service delivery networks revealed in this paper refer to the lack of resources, which hinders the involved organizations' capabilities to co-create common customer value. One example of the missing resources revealed by our data is the missing technology development: the interfaces and access to data. Proper technological solutions are an essential factor in utilizing personal data (Pikkarainen, et al., 2018). The interviewed insurance company directors commented that due to the fairly common belief that insurance companies would use data against people to lower their own costs, insurance providers might not be perceived to be ideal actors to join a network in which personal data would be mutually shared and used for co-creating end-user value. Additionally, our case study shows that many types of actors are needed in the service ecosystem to build a working data-driven service delivery network. It might be difficult to establish a new data-driven service delivery network as long as there are essential unfulfilled roles within the ecosystem. Contrary to Valkokari's (2015) definition of the innovation ecosystem as "geographically proximate actors interacting around hubs facilitated by intermediating actors", no intermediating anchor or keystone actor has emerged to facilitate actions in the preventive healthcare data-driven SDN, and not all actors are geographically close.

It has been argued that business ecosystems only create value for an individual participant if it is unable to commercialize the service relying on its own capabilities (Lin, et al., 2010). Our study shows that participation in data-driven service delivery networks may bring benefits to companies which possess capabilities to utilize shared data. It was noted, for example, that many individuals are currently coming to their occupational healthcare appointments with their own text files, where they have collected their personal data. The healthcare professionals mentioned that it would have been useful and more effective had this data been sent to their systems electronically in a modern manner, with the permission of the individuals. Thus, participation in data-driven service delivery networks may provide added value even if the participant company was able to commercialize services on it own.

Perhaps surprisingly, we did not directly identify discussions about the problems related to the wrong data and data analysis costs mentioned by Redman (2015) in our interview data. This aspect was, however, covered in the analysis in the comments in which the network actors claimed that these types of partners are needed in the future ecosystems to make this a successful business. The participating actors did not mention ethical concerns (Ruckenstein, 2014) or legal limitations (Otjacques, et al., 2007) as factors that hinder their business in the service delivery network. New benefits and challenges to have appeared from the case analysis were the use of data to increase the efficiency in healthcare organizations, and the fear of identifying the wrong target audience and payment structure. The latter seems to hinder service delivery network development, especially in the preventive healthcare domain.

Although the different perspectives of innovation networks have been widely researched in many studies in a past decade looking at e.g. the perspective of independency, stability, dynamism, collaboration, orchestration roles and practices (Hurmelinna-Laukkanen, et al., 2012) there is not much existing research which explore the factors that impact the organizational capabilities required to participate in emerging data-driven service delivery networks. The closest literature 
related to the data-driven service delivery network is the literature of digital servitization (see e.g. (Bustinza, et al., 2018; Skylyar, et al., 2019; Vendrell-Herrero, et al., 2014)), in which change in the industry due to digitalization is under the lens. Skylyar et al. (2019) argue that the mind-set of many ecosystem actors is to resist change: they are not yet fully accepting the idea leading towards disruption of the status quo. In our case, the network actors are actively seeking change, and this study explores many issues regarding the benefits and challenges of a data-driven service delivery network.

Thus, we believe that our study makes several important research contributions. First, we shed light on the challenges and the potential of the data-driven service delivery networks. In doing so, we extend the discussion about data and network concepts that has been part of the discussion. The traditional focus in the previous "big data" literature has been in the firms' internal perspective. see. e.g. (Tiefenbacher \& Olbrich, 2015; Baro, et al., 2015). When combined with data management and analytics processes, data can act as a valuable resource or asset (Xie, et al., 2016) for both the firm and its network. Typically, companies do not share data or expertise. Instead, the intention of companies has typically been to keep control over the information assets (Ctrl-Shift, 2014). Our analysis brings new perspective between a firm and its network actors, particularly in the preventive healthcare sector, where data needs to be shared between actors via consent of the individuals. Second, this study enriches the theoretical perspective of Xie et al. (2016) continuing discussion on how big data resources become cooperative assets not only in a firm but also on the larger networked level. Our findings show that using data as a resource requires the companies to have a capability to work together with other actors, creating and securing ways of sharing the high-quality data via individual consent. This data sharing is a huge opportunity especially for SMEs, which could have access to data that was previously the privilege of larger corporations and governmental bodies only. It will only be possible if an infrastructure that allows data sharing in a standard manner with relatively low costs is created. Even this does not guarantee that the service delivery network could reach the right target audience.

This study has multiple implications for practitioners trying to navigate the turbulent waters of the changing ecosystem and evolving service delivery network of preventive healthcare. Our managerial contribution lies, first, in the identification of the success factors in the benefits and challenges inherent to data-driven service delivery networks. The introduced success factors can be used as a tool when planning networked service innovation activities. With the help of the identified success factors, the different network actors can determine whether it is worthwhile for them to expend their resources to access the data-driven service market, and if they decide to do so, what are the most important issues to overcome. It was noted that especially SMEs could have key roles in the service delivery network through specializing in collecting the end-user data and, with the permission of individuals, transferring and transforming it for other players. This would make SMEs integrated parts of the service continuum, bringing them the possibility to find customers to whom they can bring added value. In preventive healthcare, however, the challenge in general is to reach those customers that are not so interested in lifestyle changes and health improvements. This is the most decisive target group in promoting health and wellness for society in general, and also from the insurance company perspective and from the health risks point of view. 
There are many possible paths to monetizing the data revolution. Choosing the right type of business and revenue model for one's organization is the key issue (Huhtala, et al., 2017). Understanding the characteristics of preventive healthcare as a service delivery network is major defining factor. Only by understanding which business model suits one's organization best can one help the players to make smart decisions on how to build, partner or acquire one's way in the next wave (Wang, 2012). This creates uncertainty related to how the revenue is distributed. It was shown in our study, that currently in the preventive healthcare domain, it seems difficult for organizations to make these decisions and to integrate a revenue model into the data-driven business opportunity. The preventive healthcare network actors seem to be waiting for others to solve the situation, or take new roles in the service delivery network to make data readily available for utilization, rather than proactively seeking to lead the revolution.

The present paper proposes factors that affect actions and change in data-driven service delivery networks, with the aim of enriching current understanding of the benefits and challenges related to the network's creation in preventive healthcare. The work is based on a case study that was conducted using a service delivery network as a unit of analysis, consisting of eight companies from the preventive healthcare sector. Some of the players are already collaborating in the same network but some were selected for the study due to their interest in joining and contributing to the service delivery network, based on identified potential business benefits. Therefore, it should be acknowledged that the studied service delivery network was in a development phase at the time of the study. Thus, the applicability of the proposed success factors should be investigated in various extant operating service delivery networks, such as in the industrial domain, to validate their universal applicability.

Sometimes building theory from cases may result in a narrow theory. Case study theory is a bottom-up approach in which the risk is that the created theory is difficult to generalize (Eisenhardt, 1989). In our study, we did not yet develop a new theory, but we rather aimed to enrich the understanding of the service delivery network, and data as a resource in value co-creation. The next step of the study is to propose a model for organizations to survive in the future data-driven service delivery networks.

Our study has its limitations. For instance, while we conducted multidisciplinary theoretical approach including e.g. the key constructs of ecosystems, service delivery, networks and data, it was not possible to go deep into one research discipline. Unable to include details with regard to different aspects, this may have caused us to miss something. Such limitations also provide a basis for future research. For example, looking at the success factors from the perspective of innovation, network orchestration would be worth further examination. Additionally, the present study opens interesting opportunities for future research. Further research is needed on the design and variety of value that the potential data-driven services could bring. Another research idea is to use the business model construct to identify additional business opportunities. For example, revenue models that could support data-driven service delivery networks both from the network- and the individual organization's perspective. It would be interesting to repeat the study of success factors in extant, successfully created service delivery networks to increase the evidence of validity. It has been argued by Skylyar et al. (2019) that longitudinal network research is needed to bring additional insights into the evolution of ecosystems. This is a relevant future research angle also to this study. Additionally, the study can be extended by providing 
specific recommendations (or an action plan) for improving the identified practices in the service delivery network.

\section{Conclusions}

In sum, real-time personal data is a vitally important resource for companies who are part of data-driven service delivery networks. However, the accessibility of data can be a major issue. The barriers to access and use data are real. The existing standards, payment models, and network roles are not clear enough for organizations to move on and start sharing and utilizing personal data.

It is certain that there will be failures. Solutions targeted for the wrong audience, individuals not realizing the value of personalization, lack of motivation to share data. When the control of data is in the hands of the individuals themselves, data operators capable of supporting people with their data are necessary. To help release personal data from organizational silos, organizations in service delivery networks should adopt a new type of effectual attitude toward business model experimentations. According to our study, it is clear that accessible personal data, as a resource, can provide a lot of opportunities and benefits for companies, insurance players, healthcare providers and individuals - if the challenges can be resolved.

\section{References}

Adner, R., 2006. Match your innovation strategy to your innovation ecosystem. Harvard Business Review, 84(4), pp. 98-107.

Akaka, M. A., Vargo, S. L. \& Lusch, R. F., 2013. The Complexity of Context - A Service Ecosystems Approach for International Marketing. Journal of International Marketing, 21(4), pp. 1-20.

Andersson, J. C., Håkansson, H. \& Johanson, J., 1994. Dyadic Business Relationships Within a Business Network Context. Journal of Marketing, October, 58(-), pp. 1-5.

Arrow, K. J., 1974. The limits of organization. New York: W.W. Norton \& Co..

Baldwin, G., 2010. Consumer-directed health care? Yes. Consumer-connected? Maybe. Health Data Management, 18(6), p. 28.

Baro, E., Degoul, S., Beuscart, R. \& Chazard, E., 2015. Toward a Literature-Driven Definition of Big Data in Healthcare. BioMed Research International, -(-), pp. 1-9.

Beirão, G., Patrício, L. \& Fisk, R. P., 2017. Value cocreation in service ecosystems: Investigating health care at the micro,meso, and macro levels. Journal of Service Management, 28(2), pp. 227249 .

Bettencourt, L., Lusch, R. \& Vargo, S., 2014. A service lens on value creation: marketing's role in achieving strategic advantage. California Managent Review, 57(1), p. 44-66. 
Brownlow, J., Zaki, M. \& Neely, A., 2015. Data and Analytics - Data-Driven Business Models: A Blueprint for Innovation, and Florian Urmetzer. Working Paper.

Burton, R. et al., 2008. Designing organizations: 21st century approaches. 1 ed. s.l.:Springer US.

Bustinza, O., Gomes, E., Vendrell-Herrero, F. \& S.Y., T., 2018. An organizational change framework for digital servitization: Evidence from the Veneto region. Strategic Change, 27(2), p. $111-119$.

Ceccagnoli, M., Forman, C., Huang, P. \& Wu, D., 2012. Cocreation of value in a platform ecosystem: the case of enterprise software. Management Information Systems Quarterly (MIS Q), 36(1), p. 263-290.

Chesbrough, H., 2007. Business model innovation: It's not just about technology anymore. Strategy \& Leadership, 35(6), pp. 12-17.

Clarysse, B., Wright, M., Bruneel, J. \& Mahajan, A., 2014. Creating value in ecosystems: Crossing the chasm between knowledge and business ecosystems. Research Policy, 43(7), p. 1164-1176.

Collins, F. S. \& Varmus, H., 2015. A New Initiative on Precision Medicine. The NEW ENGLAND JOURNAL of MEDICINE, 26 February.372(9).

Ctrl-Shift, 2014. Personal Information Management Services: An analysis of an emerging market, London, UK: Ctrl-Shift.

Dhanaraj, C. \& Parkhe, A., 2006. Academy of Management Review. Orchestrating innovation networks, 31(-), p. 659-669.

Eisenhardt, K. \& Graebner, M., 2007. Theory building from cases: Opportunities and challenges. Academy of Management Journal, 50(1), pp. 25-32.

Eisenhardt, K. M., 1989. Building Theories from Case Study Research. The Academy of Management Review, 14(4), pp. 532-550.

Ericsson, 2013. Personal Information Economy: Consumers and the Evolution of Commercial Relationships. An Ericsson Consumer Insight Summary Report, s.l.: s.n.

European commission, 2016. The EU Data Protection Reform and Big Data Factsheet 2016. [Online] Accessed Nov 1, 2018: http://ec.europa.eu/justice/data-protection/files/data-protection-big-data_ factsheet_web_en.pdf

Facebook, 2014. Facebook Annual Report 2014. Accessed Nov 1, 2018: https://s21.q4cdn.com/ 399680738/files/doc_financials/annual_reports/FB2014AR.pdf

Fink, A., Siebe, A. \& Kuhle, J., 2004. How scenarios support strategic early warning processes. Foresight, 6(3), pp. 173-185.

FitzPatrick, M., Varey, R., Grönroos, C. \& Davey, J., 2015. Relationality in the service logic of value creation. Journal of Service Marketing, 29(7), pp. 463-471.

Flores, M., 2013. P4 medicine: how systems medicine will transform the healthcare sector and society. Personalized Medicine, 10(6), pp. 565-576. 
Frow, P., McColl-Kennedy, J. R. \& Payne, A., 2016. Co-creation practices: Their role in shaping a health care ecosystem. Industrial Marketing Management, July, Volume 56, p. 24-39.

Furtado, L., Dutra, M. \& Macedo, D., 2017. Value Creation in Big Data Scenarios: A Literature Survey. Journal of Industrial Integration and Management, 2(1).

Graeff, T. \& Harmon, S., 2002. Collecting and using personal data: consumers' awareness and concerns. Journal of Consumer Marketing, 19(4), p. $302-318$.

Grierson, H., Corney, J. \& Hathcher, G., 2015. Using visual representations for the searching and browsing of large, complex, multimedia data sets. International Journal of Information Management, 35(2), pp. 244-252.

Grönroos, C. \& Voima, P., 2013. Critical service logic: making sense of value creation and co-creation. Academy of Marketing Science, Volume 41, pp. 133-150.

Henttonen, K., 2008. Doing A while hoping for B? A study of organizational innovation in three large organizations. Kuopio: Springer publishing company .

Hood, L. \& Flores, M., 2012. A personal view on systems medicine and the emergence of proactive P4 medicine: predictive, preventive, personalized and participatory. New Biotechnology, 29(6), p. 613-624.

Huhtala, T., 2018. Using personal data to advance prevetive healthcare services. Journal of Service Science Research, 10(1), pp. 77-115.

Huhtala, T., Pikkarainen, M. \& Saraniemi, S., 2017. Transformation of the Business Model in an Occupational Health Care Company Embedded in an Emerging Personal Data Ecosystem A case study in Finland. Venice, Italy, International Journal of Social, Behavioral, Educational, Economic, Business and Industrial Engineering.

Hurmelinna-Laukkanen, P. \& Nätti, S., 2018. Orchestrator types, roles and capabilities - A framework for innovation networks. Industrial marketing management, 74(-), pp. 67-78.

Hurmelinna-Laukkanen, P., Olander, H., Blonqvist, K. \& Panfiliii, V., 2012. Orchestrating R\&D networks: Absorptive capacity, network stability, and innovation appropriability. European Management Journal, 30(-), p. 552- 563.

Iansiti, M. \& Levien, R., 2004. The Keystone Advantage: What the New Dynamics of Business Ecosystems Mean for Strategy, Innovation and Sustainability. Boston, MA: Harvard Business School Press.

Jackson, D., 2015. What is an Innovation Ecosystem? Accessed Oct 28, 2015 http://erc-assoc. $\mathrm{org} / \mathrm{sites} /$ default/files/topics/policy_studies/DJackson_Innovation\%20Ecosystem_03-15-11.pdf. Kanta, 2016. Kansallinen terveysarkisto. Accessed Nov 1, 2018: http://www.kanta.fi/en/web/ ammattilaisille

Keen, P. \& Qureshi, S., 2006. Organizational Transformation through Business Models: A Framework for Business Model Design. Hawaii, US., Proceedings of the 39th Hawaii International Conference on Information Sciences. 
Kim, E., Strecher, V. \& Ryff, C., 2014. Purpose in life and use of preventive healthcare services. Proceedings of the National Academy of Sciences, 111(46), pp. 16331-16336.

Kortelainen, S. \& Järvi, K., 2014. Ecosystems: systematic literature review and framework development. Dublin, Ireland, s.n.

Koskela-Huotari, K. et al., 2016. Innovation in service ecosystems-Breaking, making, and maintaining institutionalized rules of resource integration. Journal of Business Research, Issue 69, pp. 2964-2971.

Laperche, B., Munier, F. \& Hamdouch, A., 2008. The collective innovation process and the need for dynamic coordination: general presentation. Journal of Innovation Economics \& Management, 2(-), pp. 3-13.

Lee, D., 2018. Effects of key value co creation elements in the healthcare system: focusing on technology applications. Service Business.

Lehto, I., Hermes, J., Ahokangas, P. \& Myllykoski, J., 2013. Collaboration in Cloud Businesses Value networks and ecosystems. Communications of the Cloud Software. Discussion paper.

Lim, C. et al., 2017. Using data to advance service: managerial issues and theoretical implications from action research. Journal of Service Theory and Practice.

Lin, Y., Wang, Y. \& Yu, C., 2010. Investigating the Drivers of the Innovation Channel Integration and Supply Chain Performance: A Strategy Oriented Perspective. International Journal of Production Economics, 127(-), pp. 320-332.

Lupton, D., 2012. M-health and health promotion: the digital cyborg and surveillance society. Social Theory \& Health, 10(3), p. 229-244.

Lupton, D., 2013. Quantifying the body: monitoring and measuring health in the age of mHealth technologies. Critical Public Health, 23(August), p. 393-403.

Lupton, D., 2014. Self-tracking modes: reflexive self-monitoring and data practices. Accessed Nov 1, 2018: https://ssrn.com/abstract $=2483549$

Lupton, D., 2015. Quantified sex: a critical analysis of sexual and reproductive self-tracking using apps. Culture, Health and Sexuality, 17(4), p. 1-14.

McAfee, A. et al., 2012. Big data. The management revolution. Harvard Business Review, 90(10), pp. 61-67.

McDonald, C., 1997. The Barriers to Electronic Medical Record Systems and How to Overcome Them. Journal of the American Medical Informatics Association, 4(3), pp. 213-221.

Mele, C. \& Della Corte, V., 2013. Resource-based view and Service-dominant logic: similarities, differences and further research. Journal of Business Marketing Management, 6(4), pp. 192213.

Moenaert, R. K., Caeldries, F., Lievens, A. \& Wauters, E., 2000. Communication flows in international product innovation teams. Journal of Product Innovation Management, 17(5), p. 360-377. 
Moore, J., 1996. The Death of Competition: Leadership and Strategy in the Age of Business Ecosystems. New York: Harper Collins.

Morozov, E., 2013. To Save Everything Click Here. London: Allen Lane.

Muskat, M. \& Backman, D., 2012. Mixed Methods: Combining Expert Interviews, Cross-Impact Analysis and Scenario Development. The Electronic Journal of Business Research Methods, 10(1), pp. 9-21.

MyData Alliance, 2017. MyData. Accessed Nov 1, 2018: https://mydatafi.wordpress.com/

Möller, K. \& Rajala, A., 2007. Rise of the strategic nets - New modes of value creation. Industrial Marketing Management, 36(7), pp. 895-908.

Nenonen, S. \& Storbacka, K., 2010. Business model design: conceptualizing networked value co-creation. International journal of quality and service sciences, 2(1), pp. 43-59.

Norris, J., 2012. Self-tracking may become key element of personalized medicine. Accessed Jan 1, 2018:

https://www.ucsf.edu/news/2012/10/12913/self-tracking-may-become-key-element-personalized-medicine

Ostrom, A. L. et al., 2015. Service Research Priorities in a Rapidly Changing Context. Journal of Service Research, 18(2), pp. 127-159.

Otjacques, B., Hitzelberger, P. \& Feltz, F., 2007. Interoperability of E-Government Information Systems: Issues of Identification and Data Sharing. Journal of Management Information Systems, pp. 1557-928X.

Palmer, M., 2006. Data is the new oil. Accessed Apr 1, 2017: http://ana.blogs.com/maestros/ 2006/11/data_is_the_new.html

Pikkarainen, M., Ervasti, M., Hurmelinna-Laukkanen, P. \& Nätti, S., 2017. Orchestration Roles to Facilitate Networked Innovation in a Healthcare Ecosystem. Technology Innovation Management Review, 7(9), pp. 30-43.

Pikkarainen, M., Pekkarinen, S., Koivumäki, T. \& Huhtala, T., 2018. Data as a driver for shaping the practices of a preventive healthcare service delivery network. Journal of Innovation Management, 6(1), pp. 55-79.

Pinho, N., Beirão, G. \& Patrício, L., 2014. Understanding value co-creation in complex services with many actors. Journal of Service Management, 25(4), pp. 470-493.

Poikola, A., Kuikkaniemi, K. \& Honko, H., 2014. MyData - A Nordic Model for human-centered personal data management and processing, Helsinki, Finland: Finnish Ministry of Transport and Communications.

Pujol, L., Osimo, D., Wareham, J. \& Porcu, F., 2016. Data-driven business models in the digital age: The impact of data on traditional businesses. Barcelona, s.n.

Ratia, M., Myllärniemi, J. \& Helander, N., 2018. The new era of business intelligence: Big Data potential in the private health care value creation. Meditari Accountancy Research, 26(3), pp. 531-546. 
Redman, T., 2015. Information and Technology: 4 Business Models for the Data Age. Accessed Nov 1, 2018: https://hbr.org/2015/05/4-business-models-for-the-data-age

Reypens, C., Lievens, A. \& Blazevic, V., 2016. Leveraging value in multi-stakeholder innovation networks: A process framework for value co-creation and capture. Industrial Marketing Management, 56(-), pp. 40-50.

Ruckenstein, M., 2014. Visualized and interacted life: personal analytics and engagements with data doubles. Societies, Volume 4, p. 68-84.

Ryff, C., Singer, B. \& Dienberg, L., 2004. Positive Health: Connecting wellbeing with biology. Philosophical Transactions of the Royal Society B, Biological Sciences, 359(1449), pp. 13831394.

Sawhney, M., 2006. Going Beyond the Product: Defining, Designing and Delivering Customer Solutions. In: The Service-Dominant Logic of Marketing: Dialog, Debate, and Directions. New York: M.E. Sharpe, pp. 365-380.

Schwartz, P., 2014. Property, Privacy, and Personal Data. Harvard Law Review, 117(7).

Sharon, T., 2015. Self-Tracking for health and the Qualified Self: Re-articulating autonomy, solidarity, and authenticity in an age of personalized healthcare. Philosophy Technologies.

Siggelkow, N., 2007. Persuasion with case studies. Academy of Management Journal, 50(1), p. $20-24$.

Skylyar, A., Kowalkowski, C., Tronvoll, B. \& Sörhamma, D., 2019. Organizing for digital servitization: A service ecosystem perspective. Journal of Business Research (in press).

Smorodinskaya, R., Katukov, D. \& Still, K., 2017. Innovation Ecosystems. Hawaii, US., HICSS50 .

Still, K., Huhtala, T. \& Saraniemi, S., 2016. Fintechs as business and innovation ecosystems. Kuala Lumpur, The ISPIM Innovation Summit.

Tax, S. S., McCutcheon, D. \& Wilkinson, I. F., 2013. The Service Delivery Network (SDN): A customer-centric perspective of the customer journey. Journal of Service Research, 16(4), pp. 454-470.

Tiefenbacher, K. \& Olbrich, S., 2015. Increasing the Value of Big Data Projects- Investigation of Industrial Success Stories. Hawaii, US., System Sciences (HICSS) 48th Hawaii International Conference on 294-303..

Valkokari, K., 2015. Business, Innovation, and Knowledge Ecosystems. Technology Innovation Management Review, 5(8), pp. 17-24.

Wang, R., 2012. What a big-data business model looks like. Accessed Nov 1, 2018: https: //hbr.org/2012/12/what-a-big-data-business-model

Vargo, S. \& Akaka, M., 2009. Service-Dominant Logic as a Foundation for Service Science: Clarifications. Service Science, 1(1), pp. 32-41.

Vargo, S. L. \& Akaka, M. A., 2012. Value Co-creation and Service Systems (Re)Formation: A Service Ecosystems View. Service Science, 4(3), p. 207-217. 
Vargo, S. L. \& Lusch, R. F., 2004. Evolving to a New Dominant Logic for Marketing. Journal of Marketing, Volume 68, pp. 1-17.

Vargo, S. L. \& Lusch, R. F., 2008. Service-Dominant Logic: Continuing the Evolution. Journal of the Academy of Marketing Science, 31(1), pp. 1-10.

Vargo, S. L. \& Lusch, R. F., 2011. From Goods-Dominant Logic to Service-Dominant Logic, paper presented at the Workshop on Service-Dominant Logic: An Evolution or Revolution in Marketing Theory and Practice? Concordia University, Montreal: s.n.

Vargo, S. L. \& Lusch, R. F., 2015. Institutions and axioms: an extension and update of servicedominant logic. Journal of the Academy of Marketing Science.

Vargo, S. L. \& Lusch, R. F., 2016. Institutions and axioms: an extension and update of servicedominant logic. Journal of the Academy of Marketing Science, Volume 44, pp. 5-23.

Vargo, S. \& Lusch, R., 2017. Service dominant logic 2025. International Journal of Research in Marketing, 34(1), pp. 46-67.

Vendrell-Herrero, F., Parry, G., Bustinza, O. \& O'Regan, N., 2014. Servitization as a Driver for Organizational Change. Strategic Change, 23(5-6), pp. 279-285.

Whitson, J., 2013. Gaming the quantified self. Surveillance \& Society, 11 (1/2), p. 163-176.

Xie, K., Wu, Y., Xiao, J. \& Hu, Q., 2016. Value co-creation between firms and customers: The role of big data-based cooperative assets. Information and Management, 53(8), pp. 10341048.

Zahra, S. \& Nambisan, S., 2012. Entrepreneurship and strategic thinking in business ecosystems. Business Horizons, Volume 55, pp. 519-229.

Zainuddin, N., Tam, L. \& McCosker, A., 2016. Serving yourself: Value self creation in health care service. Journal of Services Marketing, 30(6), pp. 586-60.

\section{Appendices}

\section{Appendix 1: The companies interviewed}

\begin{tabular}{lllll}
\hline ID & Sector & Type of Company & $\begin{array}{l}\text { Business and } \\
\text { services / key } \\
\text { activities }\end{array}$ & $\begin{array}{l}\text { Interviewed } \\
\text { person(s) }\end{array}$ \\
\hline A & $\begin{array}{l}\text { Technology and } \\
\text { application } \\
\text { provider }\end{array}$ & SME & $\begin{array}{l}\text { Technology provider, } \\
\text { data analytics, } \\
\text { wellness application }\end{array}$ & CEO \\
B & $\begin{array}{l}\text { Healthcare } \\
\text { service provider }\end{array}$ & $\begin{array}{l}\text { Large corporation } / \\
\text { healthcare provider }\end{array}$ & $\begin{array}{l}\text { Healthcare and } \\
\text { wellness }\end{array}$ & $\begin{array}{l}\text { Development Director } \\
\text { (Working Life } \\
\text { Services) } \\
\text { Two nurses and one } \\
\text { doctor }\end{array}$ \\
\end{tabular}




\begin{tabular}{|c|c|c|c|c|}
\hline ID & Sector & Type of Company & $\begin{array}{l}\text { Business and } \\
\text { services / key } \\
\text { activities }\end{array}$ & $\begin{array}{l}\text { Interviewed } \\
\text { person(s) }\end{array}$ \\
\hline $\mathrm{C}$ & $\begin{array}{l}\text { Insurance } \\
\text { company }\end{array}$ & $\begin{array}{l}\text { Large corporation / } \\
\text { insurance company }\end{array}$ & $\begin{array}{l}\text { Banking, financial, } \\
\text { insurance, healthcare } \\
\text { and wellness }\end{array}$ & $\begin{array}{l}\text { Chief Actuary } \\
\text { (Insurance) }\end{array}$ \\
\hline $\mathrm{D}$ & $\begin{array}{l}\text { Wellness service } \\
\text { provider }\end{array}$ & $\begin{array}{l}\text { SME, personal trainer } \\
\text { company }\end{array}$ & $\begin{array}{l}\text { Wellness trainer } \\
\text { courses }\end{array}$ & $\begin{array}{l}\text { CEO and the Director } \\
\text { of International } \\
\text { Growth and operation }\end{array}$ \\
\hline $\mathrm{E}$ & $\begin{array}{l}\text { Wellness service } \\
\text { provider }\end{array}$ & $\begin{array}{l}\text { SME } \\
\text { trainer company }\end{array}$ & $\begin{array}{l}\text { Personal trainer } \\
\text { services }\end{array}$ & Two personal trainers \\
\hline $\mathrm{F}$ & $\begin{array}{l}\text { Insurance } \\
\text { company }\end{array}$ & $\begin{array}{l}\text { Large corporation / } \\
\text { insurance company }\end{array}$ & Insurance & Two directors \\
\hline G & $\begin{array}{l}\text { Telecommunication } \\
\text { device and } \\
\text { platform provider }\end{array}$ & $\begin{array}{l}\text { Large corporation / } \\
\text { platform provider }\end{array}$ & $\begin{array}{l}\text { Mobile network } \\
\text { operator }\end{array}$ & One director \\
\hline $\mathrm{H}$ & $\begin{array}{l}\text { Wellness platform } \\
\text { provider }\end{array}$ & $\begin{array}{l}\text { SME / platform } \\
\text { provider }\end{array}$ & $\begin{array}{l}\text { Technology provider, } \\
\text { wellness application }\end{array}$ & One director \\
\hline I & $\begin{array}{l}\text { Telecommunication } \\
\text { device and } \\
\text { platform provider }\end{array}$ & $\begin{array}{l}\text { Large corporation / } \\
\text { service device and } \\
\text { platform provider }\end{array}$ & $\begin{array}{l}\text { Technology provider, } \\
\text { wellness application }\end{array}$ & Ecosystem director \\
\hline
\end{tabular}

\section{Appendix 2: The presented scenario}

Mary use case:

Mary is going for a health check. Mary is a 24-year-old pregnant woman who has just got a new job. She cares about her wellbeing, but the new job and its requirements are making her very stressed out.

Mary is exercising once a week, taking long walks, and trying to eat as healthily as possible. She is collecting information about her walking habits using a mobile application. Before the health check Mary makes a health check using a mobile application. She also transfers all of her self-collected data to the doctor.

Mary is opening a data account for her unborn child because she wants to make sure that any data transferral is as easy as possible. Mary is moving the child's insurance information and other information to the data operator so that they can easily be used in the future.

Mary fell down while walking and her wrist hurts. She is using her mobile phone to check the symptoms. Through the mobile phone she can directly chat with a nurse about the situation. Mary is asked if she wants to share her health check data with a nurse and doctor so that they can take care of her better. She is also asked if she wants to share the status information about the accident with an insurance company.

Mary has had her baby and she is back at work. Mary is really stressed out. The baby 
is keeping her awake all night and she does not have time for her weekly walks. Mary is sharing her health data with her health provider, asking for help with her situation. The system is collecting Mary's data for a few days and giving her some guidelines on how to improve her situation. At some point, the system suggests that Mary goes to talk to a nurse and psychologist about her problems. The system also suggests that Mary tries out a personalized personal trainer program that can give her specific guidelines to help improve her situation using the collected data. 


\section{Biographies}

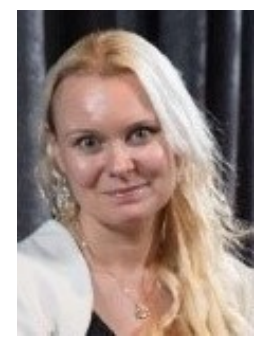

Minna Pikkarainen. Minna Pikkarainen, is a joint Connected Health professor of VTT Technical Research Centre of Finland and University of Oulu / Oulu Business School, Martti Ahtisaari Institute and Faculty of Medicine. As a professor of connected health Minna is doing on multidisciplinary research on innovation management, service networks and business models in the context of connected health service co-creation. Professor Pikkarainen has extensive record of external funding, her research has been published large amount of journal and conference papers e.g. in the field of innovation management, software engineering and information systems. During 2006-2012 Professor Minna Pikkarainen has been working as a researcher in Lero, the Irish software engineering research centre, researcher in Sirris, collective "centre of the Belgian technological industry" and business developer in Institute Mines Telecom, Paris and EIT (European Innovation Technology) network in Paris and Helsinki. Her key focus areas as a business developer has been in healthcare organizations. Previously, Minna's research has been focused on the areas of agile development, software innovation and variability management.

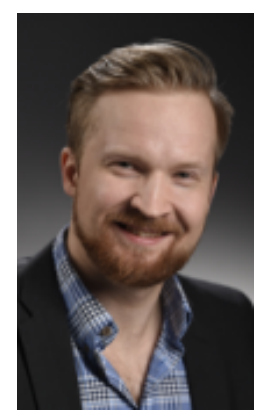

Tero Huhtala. Tero Huhtala was born in Oulu, Finland in 1984. He received the B.S. and M.S. degrees in marketing from the University of Oulu, Finland, in 2014. Since 2015, he has been a doctoral student with the department of marketing, management, and international business, University of Oulu, Oulu Business School. The topic of his doctoral dissertation is data-based value creation in service delivery networks. He has seven scientific publications, most of them regarding preventive healthcare. His research interests include the study of digitally enabled services and the value and use of data in advancing services.

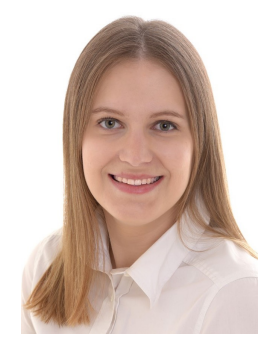

Laura Kemppainen. M.Sc. Laura Kemppainen is a Doctoral Candidate at Martti Ahtisaari Institute of Global Business and Economics at the AACSB accredited Oulu Business School, Finland. She holds a M.Sc. in Marketing from Oulu Business School. Laura's research interests include platform business models, human-centered personal data management, digital innovations and value creation. In her doctoral dissertation, the aim is to build understanding about the creation, capture and co-creation of value in the emerging data- and platform-driven ecosystems through the lens of service-dominant logic of marketing.

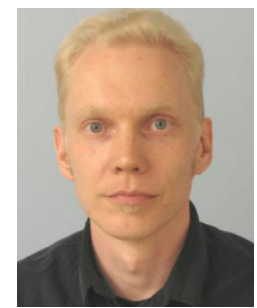

Juha Häikiö. Juha Häikiö is a research scientist at the VTT Technical Research Centre of Finland and works in the Foresight-driven Business Strategies unit. He holds an MSc in Information Processing Science. His research interests include user-centered design, user experience and digital service ecosystems. He has experience about R\&D projects focusing on digitalization in a number of different industrial sectors. 